\title{
Vegetative Associations Affecting Glaucomys volans in Central Virginia ${ }^{1}$
}

\author{
Daniel E. SONENSHINE \& Gerald F. LEVY
}

Sonenshine D. E. \& Levy G. F., 1981: Vegetative associations affecting Glaucomys volans in central Virginia. Acta theriol., 26, 23: 359-371 [With 7 Tables].

This study examined the vegetative requirements of the flying squirrel, Glaucomys volans (Linnaeus, 1758) in central Virginia. Three separate forested areas, all within $22 \mathrm{~km}$ of one another, were compared with respect to vegetation and $G$. volans distribution. Phytosociological methods were used to analyze the vegetation, while traps installed on trees in geometrically regular grids were used to determine animal distribution. Our findings suggest that the absence or extreme paucity of the shrub-liana ground cover renders an area unsuitable for breeding populations of $G$. volans. Where flying squirrels were abundant, canopy tree characteristics (e.g., height, limb spacing, bark texture, etc.), had the greatest overall influence on flying squirrel distribution. Oak or oak associated types, in combination with a dense shrub layer, represented the most nearly optimal habitat for these animals. Mixed lowland and yellow poplar, but not pine, dominated forest types were also utilized extensively. Strong positive correlations were found with shrub layer characteristics, especially density. In contrast, understory forest components had little apparent influence on flying squirrel distribution, except for cedar availability.

[Dept. Biol. Sci., Old Dominion Univ., Norfolk, Virginia 23508 (DES, GFL)].

\section{INTRODUCTION}

The southern flying squirrel, Glaucomys volans (Linnaeus, 1758) is established throughout most of the eastern and central United States, as well as parts of Canada and Mexico. The discovery of epidemic typhus (Rickettsia prowazekii) in several eastern U.S. populations of G. volans (Bozeman et. al., 1975) has increased the need for information on the ecology of this animal. An especially relevant parameter concerns the identification of the optimal habitat type for flying squirrels since this impacts directly on the human population that may also be present.

Little is known of the habitat preferences of the southern flying squirrel. Muul (1974) noted that flying squirrels were not restricted to a particular forest habitat type, and the tree species selected for nesting sites reflected those available in the different geographic areas. $\mathrm{He}$ further noted that the tree species chosen probably followed the choices

1 Supported by a contract, FDA-223-73-1188, with the Bureau of Biologics, Food and Drug Administration, U.S. Public Health Service, Department of Health and Human Services, Bethesda, Maryland 20014 USA. 
made by woodpeckers (Dendrocopos spp.) since flying squirrels normally do not excavate the cavities in which they construct nests. Other vegetative characteristics of the forest habitats which might have influenced their use by flying squirrels have not been reported.

In an effort to better characterize the habitat preferences of these animals, this study compared three separate forested areas. Two of the forest stands sustained large, permanent $G$. volans populations but the third, although clearly suitable habitat according to available literature, harbored only occasional, transient individuals.

This paper identifies vegetative characteristics important or essential to the success of $G$. volans in nature, and suggests those characteristics which, in their aggregate, define optimal flying squirrel habitat.

\section{MATERIALS AND METHODS}

\subsection{Study Areas}

Three small woodlots in the Piedmont physiographic region near Richmond, Virginia were used in this study, namely: Area $A, 12.8$ ha of mature, mixed hardwood forest, studied from 1972 to 1975; Area B, approximately $1.5 \mathrm{~km}$ distant, 4.9 ha of mature hardwood forest, studied from June to November, 1974 (a stream, Falling Creek, flowed between the 2 woodlots); and Area $C$, approximately $22 \mathrm{~km}$ distant, 7.8 ha of mixed second growth hardwood forest, studied from June 1974 to April, 1975.

\subsection{Trapping Methods}

Flying squirrels were captured by 2 methods, namely, unbaited artificial shelter traps, and baited live traps. Artificial shelter traps (Sonenshine et al., 1973) were installed on trees in the 3 areas in geometrically regular grids at intervals of $31.2 \mathrm{~m}$ as described by Sonenshine et al., (1979); 127 traps were placed in Area $A, 49$ in Area $B$, and 77 in Area $C$. Traps were monitored at regular intervals throughout the study periods. Baited live trapping, conducted only from June through September, was done with Sherman traps $(7.6 \times 7.6 \times 25.4 \mathrm{~cm})$ installed on trees at the same sites as the artificial tree shelters, at an elevation of $2.4 \mathrm{~m}$, as described by Sonenshine et al., (1979). Captured animals were ear tagged (Salt Lake City Stamp Co., Salt Lake City, Utah), and their weight, sex, estimated age (Solberger, 1943) and reproductive condition were recorded.

\subsection{Phytosociological Methods}

The vegetation was sampled using the Bitterlick circular plot method (Lindsey, 1958), as modified by Levy \& Walker (1971). Circular plots of $100 \mathrm{~m}^{2}$ were used for trees (individuals greater than $10 \mathrm{~cm}$, diameter breast height, $(b h)$ and saplings (less than 10 but more than $2.5 \mathrm{~cm} \mathrm{dbh}$ ). Circular plots of $16 \mathrm{~m}^{2}$ were used for shrubs and seedlings. Sample locations corresponded to the tree shelter locations. Plot centers were located by drafting 2 random numbers. The first, between 1 and 10, established the distance from the shelter bearing tree, the 
secord, from 1 to 60 , the direction from the tree's center. Samples were made at al shelter trap locations. The dominant canopy, understory and shrub species were determined for each site. A species that contributed more than $50 \%$ of the indiriduals in a sample was considered the dominant species. If no single species was dominant, co-dominants were assigned. Plots which had not distinguishable domnant or co-dominant species were classified as "mixed". In the understory and shrus strata, plots dominated by a species which was dominant at only one or 2 sites were classified as "other". Plots where the understory zones had 2 stems/ $100 \mathrm{n}^{2}$ or less were classified as "no cover" for those strata.

Sprecies density (mean number of individual/sample) and frequency (percent occurrence) were computed for the canopy, understory and shrub strata. Species dominance (sum basal area) was also computed for trees. The Relative Importance Value (RAV) (Levy \& Walker, 1971) of each tree species in the canopy was computed. In addition, the vegetation was described in structural and functional $(S-T)$ terms (Knight \& Loucks, 1969). Each $S-F$ character was scaled from 1 to 9 , with 1 representing the lowest preference value. Indiwiduals in a sample plot were assigned a value for each character, and the average value of every character was determined for the entire sample plot. Thus, a sample plot with $\beta$ trees, 2 with a leaf width value of 5 and the third with a value of 8 , would have a mean leaf width value of 6 . Values assigned to characters requiring subjective judgments were as follows: 1) leaf width, in order of increasing width; 2) deciduousness, in order of increasing abundance of true deciduous forms; 3) canopy height, in order of increasing height; 4) nest material, with cedar assigned the highest value; 5) limb spacing, with pine and dead trees assigned the highest values; and 6) bark texture, with rough bark assigned the highest value. Values assigned to canopy, understory and shrub-liana strata were based on flying sqirrel occurrence in the different dominant types, with data transformed by $\mathrm{Chi}^{2}$ as described below. In the case of foods, the season of crop production was based on Radford et al. (1964). Other variables studied were amenable to direct quantification and are not described further (e. g., tree diameters).

\subsection{Data Analysis}

Data on G. volans use of different forest types was transformed by $\mathrm{Chi}^{2}$. Forest types were characterized by the dominant tree species represented in the canopy. Each type was assigned a value reflecting its importance to the $\mathrm{Chi}^{2}$ sum and the transformed data analyzed by multiple correlation and regression (UCLA Computer Program BMD 02R). No comparisons with $G$. volans captures was done for Area $B$, due to the paucity of captures. G. volans use of certain dominant vegetative types for nesting, food storage and defecatoria was compared by $\mathrm{Chi}^{2}$. Differences in density and diversity of the shrub and true understory strata at the 3 study areas were evaluated by the Student's $t$-test.

\section{RESULTS}

\subsection{Vegetation of the Three Study Areas (Phytosociology)}

The 3 different areas were predominantly oak-hickory (Quercus-Carya) characteristic of the climax community expected in the region and 
superficially similar to one another. Oaks, especially white oak $(Q$. alba) and red oak (Q. rubra) were the most important canopy species, representing at least one-third of the canopy in each area (Table 1). Hickory was also important in all 3 areas, representing $9.6 \%$ to $16.2 \%$ of the canopy species. Sweet gum (Liquidambar styraciflua) was much more important in areas $A$ and $B$ than $C$, yellow poplar (Liriodendron tulipifera) was important only in area $A$, while pine (Pinus taeda) was especially abundant in area $C$. Overall, area $A$ was the most diversified of the 3 study areas, with 30 species of trees, while $B$ was the least diversified, with 23 species $(72.2 \%$ of which were oaks, hickories or sweet gum).

Table 1

Comparison of relative importance of value $(\%)$ of dominant tree species of the forest canopy at the three Virginia study areas.

\begin{tabular}{|c|c|c|c|}
\hline Tree Species & Area $A$ & Area $B$ & Area $C$ \\
\hline White oak Quercus alba & 20.8 & 17.9 & 26.8 \\
\hline Red oak Quercus rubra & 11.6 & 21.4 & 8.1 \\
\hline Yellow poplar Liriodendron tulipifera & 14.2 & 3.6 & 5.1 \\
\hline Hickory Carya sp. & 13.2 & 11.3 & 9.6 \\
\hline Sweet gum Liquidambar styraciflua & 10.3 & 11.7 & 2.1 \\
\hline Beech & 4.6 & 1.9 & 1.2 \\
\hline Red maple Acer rubrum & 5.0 & 2.9 & 2.3 \\
\hline Black gum Nyssa sylvatica & 3.0 & 1.3 & 3.7 \\
\hline Holly Ilex opaca & 2.8 & 0.8 & 3.8 \\
\hline Pine Pinus taeda & 4.6 & 6.2 & 14.7 \\
\hline Black oak Quercus velutina & 2.8 & 5.9 & 8.7 \\
\hline Spanish oak Quercus falcata & 2.5 & 2.7 & 3.0 \\
\hline Cedar Juniperus virginiana & 0.1 & 0.1 & 6.3 \\
\hline "Dead" & 0.0 & 8.3 & 4.8 \\
\hline Others & 4.7 & 4.0 & 0.0 \\
\hline
\end{tabular}

Tree species were not uniformly distributed. Seven different canopy types were recognised, reflecting differences in physiography and land use history (Table 2). Area $A$ had 6 different types, including a large mixed lowland type [(red maple, sweet gum, black gum and occasional birch (Betula nigra) and yellow poplar)] along the flood plain of the creeks. Area $B$ was the least diversified, with only 4 types. Area $C$ had 6 types, including a substantial sector dominated by pines which was absent in Area $A$.

The understory (canopy replacement and true understory) consisted mostly of the same tree species as well as holly (Ilex opaca), dcgwood, (Cornus florida), ironwood (Carpinus caroliniana), cedar (Junipenus virginiana) and sassafras (Sassafras albidum). Dead trees were strongly represented in this stratum although rare in the canopy. Diversity of understory species was least at area $B$, reflecting the gradual loss of 


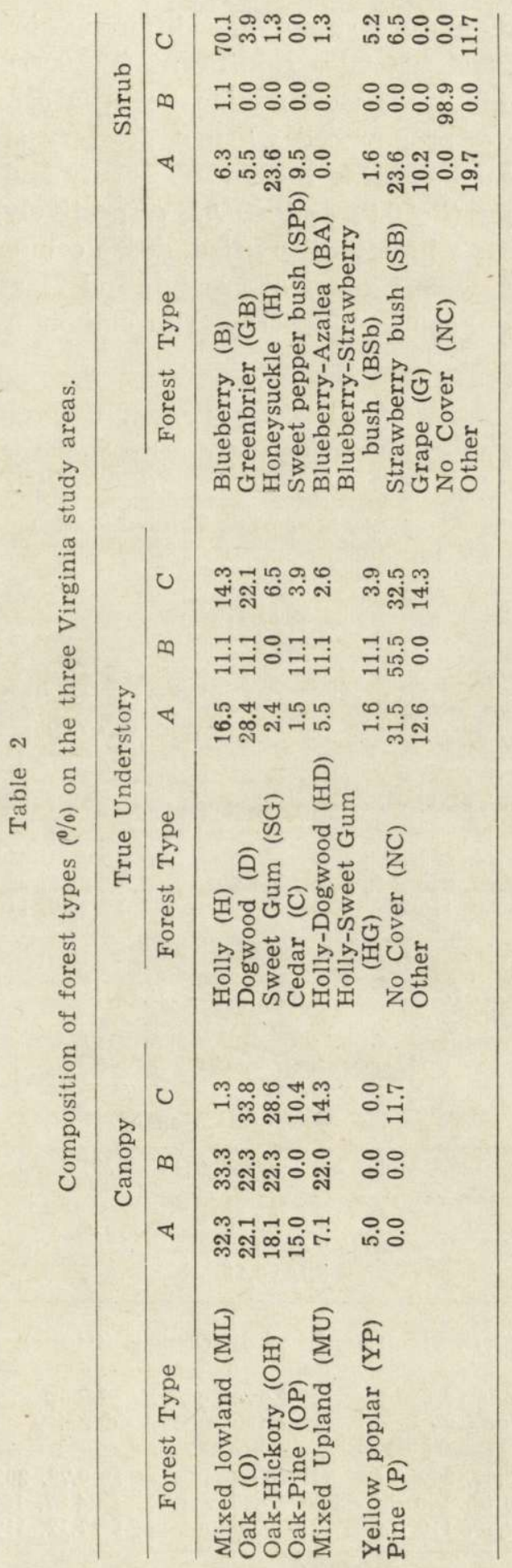


seral species in this mature stand. The difference in diversity between areas $A$ and $B$ was statistically significant $(P<0.05)$, but not between areas $B$ and $C$ (Table 3 ). The distinction between area $B$ and the other areas was even more pronounced when understory stem densities were compared, with area $B$ showing the lowest sensity and the most strongly significant difference $(P<0.01$ and $<0.02$, respectively). The shrub Iayer in areas $A$ and $C$ was a highly diversified, dense component of the forest. Twenty-two species were present at area $A$, and 21 at area $C$ (Table 4). Greenbrier (Simlax spp.), blueberry (Vaccinium spp.), honeysuckle

Table 3

Comparison of differences in diversity and density of the true understory strata of the forest habitat at the three Virginia study areas.

\begin{tabular}{ccc}
\hline \multicolumn{3}{c}{ A. Measured Values } \\
\hline Study Areas & Mean diversity \pm 2 S.E. & Mean density \pm 2 S.E. \\
\hline A & $5.11 \pm 0.41$ & $13.05 \pm 1.59$ \\
$B$ & $4.30 \pm 0.52$ & $9.20 \pm 1.43$ \\
$C$ & $4.98 \pm 0.47$ & $11.85 \pm 1.65$ \\
\hline
\end{tabular}

B. Significance of differences ( $t$ tests)

\begin{tabular}{lllll}
\hline Area compared & Mean diversity & $\begin{array}{c}\text { Level of } \\
\text { significance }\end{array}$ & Mean density & $\begin{array}{c}\text { Level of } \\
\text { significance }\end{array}$ \\
\hline$A$ vs. $C$ & $t=0.44,220$ d.f. & N.S. & $t=0.99,220$ d.f. & N.S. \\
$A$ vs. $B$ & $t=2.08,220$ d.f. & $P<0.05$ & $t=2.85,220$ d.f. & $P<0.01$ \\
$A$ vs. $C$ & $t=1.90,110$ d.f. & N.S. & $t=2.36,110$ d.f. & $P<0.02$ \\
\hline
\end{tabular}

Table 4

Comparison of differences in diversity and density of the shrub stratum at the three Virginia study areas.




(Lonicera japonica) and strawberry bush (Evonymus americana) were the most common species, frequently present in thick, tangled masses which precluded movement by all but the smallest animals. In contrast, area $B$ had a poorly developed shrub layer, with only about half the diversity and density of the shrub layer at other areas, and only 13 species represented in the sampled plots. Moreover, the shrubs were dispersed, providing little ground cover and no obstruction to movement throughout the area.

\subsection{Utilization of Vegetation Types}

G. volans captures were significantly related to the distribution of different vegetation types on areas $A$ and $C$. (Area $B$ with only 3 captures, is not considered further). Table 5 summarizes data based on

Table 5

Observed versus expected numbers of flying squirrels in different dominant vegetative types at two Virginia study areas (Tree shelter trap captures only). Abbreviations same as in Table 2.

\begin{tabular}{|c|c|c|c|c|c|c|c|c|c|c|c|}
\hline \multicolumn{4}{|c|}{ CANOPY TYPES } & \multicolumn{4}{|c|}{ TRUE UNDERSTORY } & \multicolumn{4}{|c|}{ SHRUB-LIANA } \\
\hline 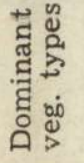 & 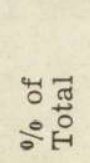 & : & 离 & 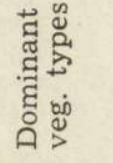 & 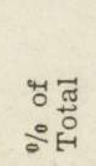 & हैं & 离 & 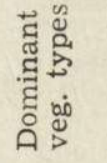 & 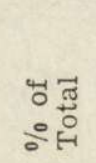 & $\overbrace{0}^{\circ}$ & 齐 \\
\hline \multicolumn{12}{|c|}{ Area A } \\
\hline MU & 7.1 & 54 & 60 & $\mathrm{H}$ & 16.5 & 103 & 139 & B & 6.3 & 81 & 53 \\
\hline & 32 & 303 & 27 & D & 2 & 280 & & GB & 5.5 & 30 & 46 \\
\hline Oak & 22.1 & 197 & 185 & SG & 2.4 & 9 & 20 & $\mathrm{H}$ & 23.6 & 287 & 199 \\
\hline \multirow[t]{2}{*}{$\mathrm{OH}$} & 18.1 & 101 & 152 & C & 1.5 & 11 & 13 & $\mathrm{SPb}$ & 9.5 & 43 & \\
\hline & & & & H-D & 5.5 & 30 & 46 & $\mathrm{BSb}$ & 1.6 & 1 & \\
\hline OP & 15.0 & 98 & 126 & H-SG & 1.6 & 20 & 13 & SB & 23.6 & 205 & 199 \\
\hline YP & 5.0 & 89 & 46 & $\mathrm{NC}$ & 31.5 & 307 & 265 & Other & 19.7 & 133 & 165 \\
\hline & & & & Other & 12.6 & 82 & 106 & & & & \\
\hline \multicolumn{4}{|c|}{$\begin{array}{c}\mathrm{Chi}^{2}=68.18, \text { d.f. }=6 \\
P<0.001\end{array}$} & Chi & $\begin{array}{r}=49.25, \\
P<0.0\end{array}$ & d.f. $=$ & & \multicolumn{4}{|c|}{$\begin{array}{c}\mathrm{Chi}^{2}=105.15, \text { d.f. }=7 \\
\qquad<0.001\end{array}$} \\
\hline
\end{tabular}

Area C

\begin{tabular}{|c|c|c|c|c|c|c|c|c|c|c|c|}
\hline MU & 14.3 & 9 & 33 & $\mathrm{H}$ & 14.3 & 45 & 33 & B & 70.1 & 151 & 161 \\
\hline ML & 1.3 & 0 & 3 & D & 22.1 & 65 & 51 & GB & 3.9 & 13 & 9 \\
\hline Oak & 33.8 & 147 & 78 & SG & 6.5 & 1 & 15 & $\mathrm{H}$ & 1.3 & 7 & 3 \\
\hline $\mathrm{OH}$ & 28.6 & 63 & 66 & C & 3.9 & 2 & 9 & $\mathrm{BA}$ & 1.3 & 9 & 3 \\
\hline OP & 10.4 & 8 & 24 & H-D & 2.6 & 13 & 6 & $\mathrm{BSb}$ & 5.2 & 14 & 12 \\
\hline $\mathrm{P}$ & 11.7 & 6 & 27 & $\mathrm{H}-\mathrm{SG}$ & 3.9 & 22 & 9 & SB & 6.5 & 16 & 15 \\
\hline & & & & $\mathrm{NC}$ & 32.5 & 47 & 76 & Other & 11.7 & 23 & 27 \\
\hline & & & & Other & 14.3 & 38 & 33 & & & & \\
\hline \multicolumn{4}{|c|}{$\begin{aligned} \mathrm{Chi}^{2}= & 103.41, \text { d.f. }=5 \\
& P<0.001\end{aligned}$} & \multicolumn{4}{|c|}{$\begin{array}{c}\mathrm{Chi}^{2}=63.99, \text { d.f. }=7 \\
P<0.001\end{array}$} & \multicolumn{4}{|c|}{$\begin{array}{c}\mathrm{Chi}^{2}=20.61 \text { d.f. }=5 \\
\mathrm{P}<0.001\end{array}$} \\
\hline
\end{tabular}


captures from tree shelters. If canopy vegetation is examined alone, the mixed lowland and oak dominated types are found to have been utilized most while the oak and pine types were utilized least. At area $A$, sites dominated by yellow poplar were especially preferred. These associations occurred at substantial distances from standing water (at $32 \mathrm{~m}, \mathrm{Chi}^{2}=$ $=63.3, P<0.01$, at $64 \mathrm{~m}, \mathrm{Chi}^{2}=53.7, P<0.01$ ), even though proximity to aquatic habitat is reported to affect $G$. volans distribution (Muul, 1968). If understory is examined alone, dogwood dominated sites appear to have attracter greater numbers of flying squirrels at both study areas. Holly, alone or in combination, appears to have been important in area C. Absence of understory did not totally exclude squirrels; in area $A$, many more squirrels than expected were found. If the shrub layer is

Table 6

Utilization of multi-level forest associations by flying squirrels as determined by capture frequency.

\begin{tabular}{|c|c|c|c|}
\hline $\begin{array}{c}\text { Forest } \\
\text { Canopy/Understory/Shrub }\end{array}$ & $\begin{array}{c}\text { Total } \\
\text { Captures }\end{array}$ & $\begin{array}{l}\text { Exp. } \\
\text { Captures }\end{array}$ & $\begin{array}{c}\% \text { all } \\
\text { Captures }\end{array}$ \\
\hline
\end{tabular}

AREA $A$

$\mathrm{ML} / \mathrm{D} / \mathrm{H}-\mathrm{Sb}$

All Oak Types/DH/S-Sb-Bb

$\mathrm{ML} / \mathrm{NC} / \mathrm{H} / \mathrm{Sb}$

All Oak Types/NC/mixed shrubs

Tulip/mixed understory/mixed shrubs

All Oak Types/NC/H-Sb-Bb

Tulip/NC/mixed shrubs

All other associations (35)

\begin{tabular}{rrr}
168 & 66.3 & 20.0 \\
119 & 19.6 & 14.1 \\
107 & 99.5 & 12.7 \\
68 & 33.2 & 8.1 \\
59 & 19.9 & 7.0 \\
55 & 53.0 & 6.5 \\
46 & 19.9 & 5.5 \\
220 & 470.0 & 26.1 \\
\hline
\end{tabular}

AREA $C$

All Oak Types/D-H/Bb-Sb

All Oak Types/NC/Bb

All Oak Types/mixed understory/mixed shrubs

All other associations (28)

\begin{tabular}{rrr}
127 & 54.5 & 54.5 \\
40 & 33.3 & 17.2 \\
32 & 18.2 & 13.7 \\
34 & 127.1 & 14.6 \\
\hline
\end{tabular}

examined alone, blueberry, separately or in combination, and honeysuckle dominated sites were found to have been utilized most.

Tests of the relationships between $G$. volans distribution and vegetation were also made with baited live trap captures, but only in area $A$. Tie highly significant relationship with canopy vegetation found with tree shelter traps was also found with baited live traps $\left(\mathrm{Chi}^{2}=25.89, P<0.0\right.$ ); again, oak and yellow poplar dominant sites were important. However, no relationship was found between baited live trap captures and tie composition of the understory or shrub strata $\left(\mathrm{Chi}^{2}=10.85, P>0.10\right.$, n.s.; $\mathrm{Chi}^{2}=9.17,>0.10$, n.s.).

To assess the interaction of all three forest strata, i.e., canopy, understory, and shrub, on flying squirrel sheltering or foraging activity, tie 
sites were compared in relation to intensity of their use. Table 6 lists the forest strata combinations which were highly utilized, (i.e., had at least $5 \%$ of all captures), and yielded significantly greater numbers of captures than expected. These 7 associations produced almost $3 / 4$ of all captures made in this area. Eight other associations were found with slightly more captures than expected, but none contributed more than $2 \%$ of all animals taken; 27 other stratum combinations produced fewer captures than expected, or none at all. Mixed lowland, yellow poplar or types with a high representation of oak, in combination with dogwood, holly, honeysuckle, strawberry and/or blueberry, were the most important associations. The absence of understory (NC, i.e., no cover, in Table 6) did not deter G. volans use, with 76 more squirrel captures at these sites than expected. In area $C$, similar relationships were found involving types with abundant oak and the same understory and shrub species. In summary, oak or oak associated types, in combination with a dense shrub layer, represented the most nearly optimal type for $G$. volans, based on site selection by these animals. Mixed lowland and yellow poplar dominated types, both relatively hydric communities situated near standing fresh water, were also important. Understory did not appear to be essential for use of any of the aforementioned types, although dogwood and holly were common components of the most intensively used habitats.

\subsection{Structural-Funetional (S-F) Analysis}

The results of this analysis are listed in Table 7. Several habitat features were found to exhibit highly significant positive correlations with flying squirrel captures. In area $A$, canopy tree characteristics had the greatest overall influence on flying squirrel captures, with tree height, leaf width, reduced limb spacing frequency and bark texture all exhibiting strong positive correlations. With the exception of cedar availability, the understory stratum was relatively unimportant. Strong positive correlations were found with the shrub layer, primarily with density, and secondarily with summer food production. Food characteristics were relatively unimportant for sheltering or nesting animals, with low or negative correlation values, except in the case of shrub summer food production as noted above. Foraging animals (baited live trap captures) also exhibited strong positive correlations with certain canopy tree characteristics, namely reduced limb spacing and bark texture; however, tree height and the correlated diameter and basal area parameters were insignificant for foraging animals. The understory layer 
was more important for foraging flying squirrels, (but only with regard to diversity) and cedar availability was especially important. The shrub layer did not contribute as strongly to foraging as it did to sheltering activity, but shrub summer food production remained a strong attraction.

Table 7

Flying squirrel capture frequency in relation to 26 different vegetative characteristics of the forest habitat at two different study areas in Virginia ${ }^{1}$.

\begin{tabular}{|c|c|c|c|c|c|c|}
\hline \multirow[b]{2}{*}{$\begin{array}{l}\text { Vegetative } \\
\text { Characters }\end{array}$} & \multicolumn{3}{|c|}{ Area $A$} & \multicolumn{3}{|c|}{ Area $C$} \\
\hline & $\begin{array}{l}\text { Tree } \\
\text { Shelters }\end{array}$ & $\begin{array}{l}\text { Baited } \\
\text { Live } \\
\text { Traps }\end{array}$ & $\begin{array}{c}\text { All } \\
\text { Captures }\end{array}$ & $\begin{array}{c}\text { Tree } \\
\text { Shelters }\end{array}$ & $\begin{array}{l}\text { Baited } \\
\text { Live } \\
\text { Traps }\end{array}$ & $\begin{array}{c}\text { All } \\
\text { Captures }\end{array}$ \\
\hline $\begin{array}{l}\text { Canopy Tree Type } \\
\text { (dominants) }\end{array}$ & 0.119 & 0.090 & 081 & -0.044 & -0.215 & -0.167 \\
\hline Mast Crop & 0.0 & & & 0.006 & 0.101 & 0.017 \\
\hline Fruit Product & -0.188 & -0.121 & -0.196 & -0.040 & 0.005 & -0.041 \\
\hline $\begin{array}{l}\text { Seed Production } \\
\text { Tree Food Prod. }\end{array}$ & 0.052 & -0.045 & 0.034 & -0.083 & -0.154 & -0.100 \\
\hline $\begin{array}{l}(\%) \\
\text { Tree Food Prod. Sum. }\end{array}$ & -0.125 & -0.104 & -0.137 & 0.000 & 0.000 & 0.000 \\
\hline $\begin{array}{l}\text { Tree Food Prod. Fall } \\
\text { Tre }\end{array}$ & 0.066 & 0.021 & 0.063 & -0.123 & 0.088 & 0.116 \\
\hline$(\%)$ & -0.035 & -0.022 & -0.036 & 0.014 & -0.141 & 0.000 \\
\hline Composition & 0.078 & -0.023 & $0 .($ & -0.0 & & -0.006 \\
\hline Leaf Widt & & $0 .($ & 0. & 0.0 & -0 . & 0.014 \\
\hline Deciduousness & 0.023 & 0.073 & 0.039 & 0.139 & 0.1 & 0.157 \\
\hline Canopy Tree Height & 0.208 & 0.081 & 0.203 & -0.015 & 0.023 & -0.013 \\
\hline Tree Hole Avail. & -0.053 & -0.119 & -0.077 & -0.054 & $0 .($ & -0.045 \\
\hline Nest Material & -0.014 & 0.141 & 0.0 & -0.051 & -0.2 & -0.073 \\
\hline Limb Spacing & 0.193 & 0.170 & 0.2 & 0.017 & 9 & 0.003 \\
\hline Bark Texture & 0 & 0.270 & 0 & $0 .($ & -0 & 0.053 \\
\hline Tree Diameter & & -0.062 & & $0 .($ & 5 & 0.050 \\
\hline Basal Area & -0.042 & -0.114 & -0.066 & -0.013 & 0.249 & 0.012 \\
\hline Understory Diversity & -0.070 & 0.165 & 0.018 & 0.061 & -0.085 & 0.053 \\
\hline Understory Density & -0.035 & 0.062 & -0.0 & 0.0 & 0.0 & 0.083 \\
\hline Evergreen $(\%)$ & -0.025 & -0.089 & 0.045 & 0.050 & 0.007 & 0.050 \\
\hline Cedar Avail. & & 0.449 & & -0.038 & -0 & 0.050 \\
\hline Shrub Divers & & 0.0 & 0.1 & $0 .($ & -0 . & 0.003 \\
\hline $\begin{array}{l}\text { Shrub Density } \\
\text { Shrub Food Prod. }\end{array}$ & $01:$ & 00 & 01 & -0.095 & 0.235 & 0.072 \\
\hline $\begin{array}{l}\text { Shrub Food Prod. Spr. } \\
(\%)\end{array}$ & -0.098 & -0.044 & 0.098 & 0.051 & 041 & 2 \\
\hline $\begin{array}{l}\text { Shrub Food Prod. Sum. } \\
\quad(\%) \\
\text { Shrub Food Prod. Fall }\end{array}$ & 0.173 & 0 . & 0.19 & 0.059 & .035 & 0.057 \\
\hline$(\%)$ & -0.169 & -0.160 & -0.190 & -0.061 & 0.043 & 0.057 \\
\hline
\end{tabular}

1 Values tabulated are results of stepwise, multiple regression analyses.

Overall, canopy tree species characteristics (i.e., height, leaf width, bark texture, and limb spacing), cedar availability, and shrub layer characteristics, exhibited the strongest and most consistent influence throughout the year. Again, food characteristics were unimportant for foraging animals, with the exception of shrub summer food production, and the 
correations exhibited very low or even negative values. In area $C$, correlations with $S-F$ characters were much weaker than in A, perhaps because of the much smaller data sample. Deciduousness, i.e., the degree to which the site was dominated by deciduous trees, was consistently important in this study area. Tree diameter and basal area, normally associated with tree size, were important for foraging animals. Again, no importance was attributed to the understory characters, but shrub density was very important for foraging animals.

\section{DISCUSSION}

The composite forest community, rather than just the canopy species, appears to determine the suitability of an area for the southern flying squirrel. Our findings suggest that extreme reduction of the shrub and understory strata render a wooded area unsuitable for breeding populations of this species. This was evident at area $B$, a woodlot virtually devoid of a shrub-liana layer. A dense shrub-liana stratum minimizes the exposure of $G$. volans to predators, especially while the rodents are active on or near the ground. Moreover, many of the shrubs provide an important summer food source (Muul, 1968) prior to the availability of acorns, nuts and other mast. In Virginia, honeysuckle, strawberry bush and blueberry bush were the shrub species most frequently found in sites utilized by $G$. volans. Elsewhere in Virginia, the authors observed G. volans nesting in the densely wooded, swampy area along an isolated beaver pond, but not in the mature oak-hickory forest on an adjacent hillside. The former habitat had a dense shrub-liana layer, while the latter habitat had only occasional, scattered shrubs. In northern Louisiana, Goertz et al. (1975) found G. volans selection to be about 20 times greater for a young, second growth pine-hardwood forest than for a mature hardwood stand. Unfortunately, the character of the shrubliana strata in these two habitats was not described, although it is expected to be much denser in the former.

In contrast to the findings for the shrub-liana layer, the presence or absence of an understory layer had no apparent influence on $G$. volans aggregations. The only exception was the importance of cedar, the bark of which is used for nest construction. Contrary to the observations of Muul (1968) and Goertz et al. (1975), cedar bark was the only natural fiber used for this purpose in the three Virginia study areas.

Canopy tree associations of the flying squirrel over an extended geographic range were studied by Muul (1974). According to this author, $G$. volans is opportunistic, accepting suitable cavities in virtually any tree. In the northern states, however, oaks were utilized most often Acta theriol., 7 
with more than $60 \%$ of the nests recorded by Muul found in these trees. Madden (1974), in her study of G. volans on Long Island, N.Y., noted that hickory trees were an important component of the habitat. with hickory nuts serving as the major food source during fall and winter. Depicting the flying squirrel as an opportunistic animal with little concern as to its choice of nest or densities may be an oversimplification. Our findings suggest that canopy vegetation influences flying squirrel use of different habitats, though not as strongly as the shrub layer. Mixed lowland, oak and yellow poplar dominated types were utilized with significantly greater frequency, even when the influence of freshwater (Sonenshine et al., 1979) was excluded. Pine and oak-pine dominated areas were utilized infrequently and nests of food caches were never observed in cavities in pine trees or shelters attached to such trees. The results of the structural and functional analyses also support the association with selected tree types. Strong, positive associations were found with extreme height, increasing leaf width and coarse bark texture, features consistent with the older mature stands of oak, yellow poplar and, to a lesser extent, red maple, where these occur in combination with a dense shrub-liana stratum.

Further studies in different geographic areas are needed to determine whether the habitat requirements of the flying squirrel described here reflect their needs throughout their range, or are only a regional phenomenon.

Acknowledgements: We are indebted to Mr. Herb Dorsey, Management Systems, Bureau of Biologics, FDA, USPHS, for computer analyses used in this stud:. We are grateful to Mr. Thomas Walker for his assistance in trapping animali and vegetational sampling while at Old Dominion University. Finally, we with to thank Ms. Zippora Katz for translating the summary of this article into Folish.

\section{REFERENCES}

1. Bozeman F. M., Masiello S. A., Williams M. S. \& Elisberg B. L., 1975: Epidemic typhus rickettsiae isolated from flying squirrels. Nature, 255: $545-547$.

2. Goertz J. W., Dawson R. M. \& Mowbray E. M., 1975: Response to nest joxes and reproduction by Glaucomys volans in northern Louisiana. J. Mamm, 56, 4: $933-939$.

3. Knight D. H. \& Loucks O. L., 1969: A quantitative analysis of Wisonsin forest vegetation on the basis of plant function and gross morphology. Ecdogy, 50: 219-234.

4. Levy G. F. \& Walker S., 1971: The combined Bitterlick-range finder cirular quadrat method in phytosociological studies. Jeffersonia, 5: 37-39.

5. Lindsey A., 1958: Field efficiencies of forest sampling methods. Ecology 39: $428-444$. 
6. Madden J. F., 1974: Female territoriality in a Suffolk County, Long Island, population of Glaucomys volans. J. Mamm., 55, 3: 647-652.

7. Muul I., 1968: Behavior and physiologic influences on the distribution of the flying squirrel, Glaucomys volans. Misc. Publ. Mus. Zool., Univ.-Michigan, 134: $1-66$.

8. Muul I., 1974: Geographic variation in the nesting habits of Glaucomys volans. J. Mamm., 55, 4: 840-844.

9. Radford A. E., Ahles H. E. \& Bell C. R., 1964: Manual of the vascular flora of the Carolina. The University of North Carolina Press, Chapel Hill, N.C. $1183 \mathrm{pp}$.

10. Solberger D. E., 1943: Notes on the breeding habits of the eastern flying squirrel Glaucomys volans. J. Mamm., 24: 163-173.

11. Sonenshine D. E., Cerretani D. G., Enlow G. \& Elisberg B. L., 1973: Improved methods for capturing wild flying- squirrels. J. Wildl. Manage., 37, 4: 588-590.

12. Sonenshine D. E., Lauer D. M., Walker T. C. \& Elisberg B. L., 1979: The ecology of Glaucomys volans Linnaeus, 1958 in Virginia. Acta theriol. 24, 26: $363-377$.

Accepted, February 12, 1981.

Daniel E. SONENSHINE i Gerald F. LEVY

\section{STRUKTURA ROSLINNOSCI A ROZMIESZCZENIE GLAUCOMYS VOLANS (LINNAEUS, 1758) W SRODKOWEJ VIRGINII}

\section{Streszczenie}

Zbadano relacje między roślinnością i rozmieszczeniem assapana Glaucomys volans (Linnaeus, 1758) w centralnej Virginii, w trzech obiektach leśnych, odległych od siebie o $22 \mathrm{~km}$. W analizie roślinności zastosowano metody fitosocjologiczne, obejmujące charakterystyki strukturalne i funkcjonalne. Assapany łowiono w pułapki ustawione na drzewach $w$ regularnej więźbie punktów odłowu $(31.2 \times$ $\times 31.2 \mathrm{~m})$.

Badania wykazały, że miejsca gdzie pokrycie warstwy krzewów i pnączy jest skąpe lub zupełnie go brak, są nieodpowiednie dla bytowania populacji G. volans. W innych kompleksach assapany byly bardzo liczne a charakterystyczne cechy drzewostanu jak wysokość, rozmieszczenie gałęzi, rodzaj kory itd. miały na ogół największy wpływ na rozmieszczenie zwierząt. Dąbrowy w kombinacji $z$ gęstą warstwą krzewów stwarzały najbardziej optymalne warunki bytowania G. volans. Nizinne lasy mieszane $\mathrm{z}$ przewagą topoli, były też intensywnie wykorzystywane przez assapany, natomiast lasy w których dominowała sosna były raczej omijane.

Wykazano silną dodatnią korelację zagęszczenia warstwy krzewów i zasiedlenia lasu przez assapany. Struktura roślinności niższego piętra wykazywała mały związek z rozmieszczeniem tych ssaków. 